\title{
Predominant causes and types of orofacial injury in children seen in the emergency department
}

\author{
Acil servise başvuran çocuk hastalarda gözlenen \\ orafasiyel yaralanma tipleri ve sık karşılaşılan nedenleri
}

\author{
Gamze AREN, ${ }^{1}$ Elif SEPET, ${ }^{1}$ Arzu PINAR ERDEM, ${ }^{1}$ Ceren Güney TOLGAY, ${ }^{1}$ \\ Sinem KURU, ${ }^{1}$ Cemalettin ERTEKİN, ${ }^{2}$ Recep GÜLOĞLU, ${ }^{2}$ Acar AREN ${ }^{3}$
}

\section{BACKGROUND}

The aim of this study is to determine the type and cause of traumatic orofacial injuries in children up to 18 years of age.

\section{METHODS}

This retrospective study involved data collected from 12055 patients that came to Istanbul University, Medical Faculty, Department of Emergency in 2011. The patients' data were evaluated with regard to age, gender, etiologic factor of the trauma, type and localization of the injury, and time interval between injury and treatment.

\section{RESULTS}

A total of 1296 children in 12055 patients with orofacial trauma were evaluated. Trauma incidence was higher in boys $(65 \%)$. The major etiologic factor of injury was falls $(56 \%)$ and primary localization was in the frontal region (41\%). The most frequent types of injury were laceration (30.1\%) and hematoma (18.6\%). 4\% of the injuries were found in the orodental region including lips, teeth, tongue and oral mucosa of the mouth. $38 \%$ of the patients came to the emergency department within 30-60 minutes after the injury and $68 \%$ were sent home with symptomatic treatment.

\section{CONCLUSION}

Considering the high percentage of orofacial traumas, effective education is necessary regarding the appropriate diagnostic approach, emergency management and prevention of traumatic dental injuries.

Key Words: Child; orofacial trauma; tooth.

\section{$\boldsymbol{A M A C}$}

Bu çalışmanın amacı, 18 yaşına kadar olan çocuk hastalarda travma nedeniyle oluşan orafasiyel yaralanmaların tipini ve nedenlerini belirlemektir.

\section{GEREC VE YÖNTEM}

Bu geriye dönük çalışma, 2011 yılında İstanbul Üniversitesi Tıp Fakültesi Acil Servis'ine başvuran 12055 hastadan toplanan bilgileri kapsamaktadır. Hastalardan elde edilen bilgiler yaş, cinsiyet, travmanın etyolojisi, tipi, yerleşimi ve yaralanma ile tedavi arasındaki zaman aralığı dikkate alınarak değerlendirildi.

\section{BULGULAR}

Orafasiyel yaralanma gözlenen 12055 hastadan 1296 çocuk hasta değerlendirmeye alındı. Erkek çocuklarda travma görülme sıklığının daha fazla olduğu saptandı (\%65). Yaralanmalarda başlica nedenin düşme $(\% 56)$ ve birincil lokasyonun frontal bölge olduğu (\%41) belirlendi. En sık karşılaşılan yaralanma tipinin laserasyon $(\% 30,1)$ ve hematom $(\% 18,6)$ olduğu saptand. Yaralanmaların \%4'ünün oradental bölgede olduğu dudakları, dişleri, dil ve oral mukazayı kapsadığı belirlendi. Hastaların \%38'inin acil servise yaralanmadan 30-60 dakika sonra başvurduğu ve \%68'inin semptomatik tedaviden sonra taburcu edildiği belirlendi.

\section{SONUÇ}

Sık karşılaşılan orafasiyel travmalar göz önünde bulundurularak doğru tanı, acil tedavi yaklaşımı ve travmatik dental yaralanmaları önlemek adına etkin eğitimin gerekli olduğu unutulmamalidir.

Anahtar Sözcükler: Çocuk; orafasiyel travma; diş.
${ }^{1}$ Department of Pedodontics, Istanbul University Faculty of Dentistry,

Istanbul; ${ }^{2}$ Department of General Surgery, Istanbul University Istanbul Faculty of Medicine, Istanbul; ${ }^{3}$ Department of General Surgery, Istanbul Education and Research Hospital, Istanbul.
'İstanbul Üniversitesi Diş Hekimliği Fakültesi, Pedodonti Anabilim Dalı, İstanbul; ${ }^{2}$ İstanbul Üniversitesi İstanbul Tip Fakültesi, Genel Cerrahi Anabilim Dalı, İstanbul; '3̇stanbul Eğitim ve Araştırma Hastanesi, Genel Cerrahi Kliniği, İstanbul.

Correspondence (İletişim): Gamze Aren, M.D. İstanbul Üniversitesi Diş Hekimliği Fakültesi, Pedodonti Anabilim Dalı, Kat: 3, Fatih, İstanbul, Turkey. Tel: +90 - 212 - 4142020 / 30283 - 3030 e-mail (e-posta): gamzearen@hotmail.com 
Orofacial trauma is a serious public health problem among children, with most injuries constituting dental emergencies that require immediate assessment and management. ${ }^{[1]}$ Dental-related emergencies including orofacial traumas and their dental complications commonly present for management by medical practitioners through hospital Emergency Departments (ED) and consulting rooms. ${ }^{[2]}$ Whereas trauma to the facial bone structures is usually referred to oral and maxillofacial or plastic surgeons, ${ }^{[3]}$ mild to moderate dental trauma and associated dental pain are collectively often not seen to be as important or might be overlooked in the context of other injuries. If there is delayed or lack of treatment, these conditions often have a persistent and negative effect on patients in terms of both cost and suffering. ${ }^{[4-6]}$

Over the past three years, a number of studies have reported the types and prevalence of orofacial injuries seen in hospital emergency departments. ${ }^{[1]}$ The information gathered in these studies provides useful descriptions of the common types of traumatic oral injuries that pediatric emergency care providers may encounter. Studies of the incidence, etiology, and distribution of these traumatic injuries provide health care planners with pertinent information to determine what types of emergency services should be available in the emergency department setting.

The aim of this retrospective study is to determine the type and etiology of traumatic orofacial injuries, including injuries to soft tissue and bones, seen in children up to 18 years of age who came to Istanbul University Faculty of Medicine, Istanbul from Jan 1, 2011, to Dec. 31, 2011 and to determine the referral patterns for further treatment.

\section{MATERIALS AND METHODS}

A retrospective design was used to address the aim of this investigation. Patient records and corresponding standard trauma form for 2011 were analysed retrospectively. All information regarding dental trauma was carefully screened, classified and allocated according to gender, age of the child at the time of trauma, type of injury, etiologic factors, injured region, treatment and the time elapsed between trauma and emergency care and diagnosis including soft tissue and bone injuries. Cases where the treatment protocol was insufficiently documented were grouped separately.

\section{RESULTS}

This retrospective study included patients between the ages of 0-18 years, visiting the Emergency Service Department at Istanbul University Faculty of Medicine, Istanbul, with dentofacial complaints during the year 2011. Of the 12055 examined records, 1296 patients met the study criteria. Trauma incidence was higher in boys $(65.0 \%)$ and in children less than five years of age $(57.4 \%)$. The gender distribution of patients is shown in Table 1.

Table 1. Gender distribution of patients with orofacial trauma

\begin{tabular}{lcc}
\hline Gender & $\mathrm{n}$ & $\%$ \\
\hline Male & 837 & 65 \\
Female & 459 & 35 \\
\hline
\end{tabular}

Table 2. Prevalence of orofacial trauma by age

\begin{tabular}{lcc}
\hline Age distribution & $\mathrm{n}$ & $\%$ \\
\hline 0 - 1 years & 37 & 2.8 \\
1 - 2 years & 177 & 13.6 \\
2 - 5 years & 531 & 41 \\
6 - 10 years & 306 & 23.7 \\
$11-18$ years & 245 & 18.9 \\
\hline
\end{tabular}

Table 3. Distribution of episodes of orofacial trauma by etiologic factor

\begin{tabular}{lcc}
\hline & $\mathrm{n}$ & $\%$ \\
\hline Fall & 730 & 56 \\
Hitting the head & 365 & 28.1 \\
Traffic accident & 100 & 7.7 \\
Being hit by a sharp object & 49 & 3.7 \\
Assault & 39 & 3 \\
Epileptic seizure & 2 & 0.15 \\
Burn & 2 & 0.15 \\
Suicide & 1 & 0.05 \\
Self-destructive behaviour & 1 & 0.05 \\
Syncope & 1 & 0.05 \\
Drowning & 1 & 0.05 \\
\hline
\end{tabular}

Table 4. Prevalence of orofacial trauma by the localization of the injury

\begin{tabular}{lcc}
\hline Localization of the injury & $\mathrm{n}$ & $\%$ \\
\hline Frontal region & 734 & 41 \\
Parietal region & 220 & 12.2 \\
Nasal region & 173 & 10 \\
Orbital region & 171 & 9.9 \\
Occipital region & 156 & 9 \\
Eyebrows & 103 & 5 \\
Orodental region & 83 & 4 \\
Mandibular region & 52 & 3 \\
Maxillary region & 20 & 1.6 \\
Unspecific localization & 28 & 1.4 \\
Cheeks & 17 & 1 \\
Ears & 15 & 0.8 \\
Zygoma & 11 & 0.6 \\
Glabella & 6 & 0.3 \\
Neck & 5 & 0.2 \\
\hline
\end{tabular}


The prevalence of orofacial injuries in patients according to their age at the time of trauma was higher in younger children (Table 2).

When considered separately, trauma caused by falls was the most predominant etiologic factor $(56.0 \%)$ as shown in Table 3.

In the 1296 patients, orofacial injuries were seen in 1794 different locations, with some patients having more than one injured region. The frontal region was the most affected area (41\%); the distribution is shown in Table 4.

A total of 83 injuries were seen in the orodental region, involving the lips, teeth, oral mucosa, tongue and gingiva. Lips $(79.5 \%)$ were the most affected area followed by teeth (15.7\%) (Table 5).

Soft tissue injuries, including lacerations, hematomas, and abrasions, were present in $65.2 \%$ of our study group (Table 6).

Patients sought help for primary care at the emergency department of Medical Faculty of Istanbul. For 1275 injuries, it was possible to evaluate time elapsed between the trauma and the initial treatment. 97\% of the patients came to the emergency department within the first 24 hours after injury (Table 7).

Symptomatic treatment was the most frequently observed treatment. After primary trauma care, $68 \%$ of the patients were sent home with medical advice; 160 patients $(12.2 \%)$ were sent to other clinics but none of them were sent for dental consultation within the first 24 hours. 60 patients $(4.8 \%)$ overruled any treatment options and 46 of them (3.5\%) left without permission (Table 8).

\section{DISCUSSION}

The determination of the incidence and prevalence of orofacial trauma has some difficulties. For example, there are many different specifications of dental and oral trauma reported in the literature. ${ }^{[7-12]}$ Determining the incidence of a particular event requires information on the number of new cases in a specified time period divided by the number of persons exposed to the risk during this period. ${ }^{[7]}$ The prevalence of orofacial trauma in various epidemiological studies has also been found to differ considerably. The great variation may be due to a number of different factors such as the trauma classification, and geographical and behavioral differences between study locations and countries. ${ }^{[7]}$ This study evaluated orofacial trauma and injuryassociated factors in children who visited an emergency department. A total of 1296 children in 12055 patients with orofacial trauma from 0 to 18 years of age were evaluated. Most of the orofacial trauma data available in the literature has been collected retrospectively from cross-sectional studies or from longitudi-
Table 5. Distribution of orodental region injuries

\begin{tabular}{lcc}
\hline Injuries in orodental region & $\mathrm{n}$ & $\%$ \\
\hline Lips & 66 & 79.5 \\
Teeth & 13 & 15.7 \\
Oral mucosa & 2 & 2.4 \\
Tongue & 1 & 1.2 \\
Gingiva & 1 & 1.2 \\
\hline
\end{tabular}

Table 6. Prevalence of injury type in all patients

\begin{tabular}{lcc}
\hline Type of injury & $\mathrm{n}$ & $\%$ \\
\hline Laceration & 428 & 30.1 \\
Hematoma & 262 & 18.6 \\
Abrasion & 226 & 16.5 \\
Swelling & 148 & 10.6 \\
Ecchymosis & 138 & 10 \\
Fracture & 135 & 9.5 \\
Hypersensitivity & 32 & 2.3 \\
Hemorrhage & 15 & 1 \\
Hyperemia & 12 & 0.8 \\
Otorrhea & 7 & 0.4 \\
Dental injuries & 4 & 0.05 \\
Epistacsis & 3 & 0.04 \\
Deformity & 3 & 0.04 \\
Pain & 2 & 0.02 \\
Paralysis & 2 & 0.02 \\
Deviation & 1 & 0.01 \\
Finger marks & 1 & 0.01 \\
Burn & 1 & 0.01 \\
\hline
\end{tabular}

Table 7. Distribution of the time period between injury and treatment in orofacial trauma patients

\begin{tabular}{lcc}
\hline Time elapsed before treatment & $\mathrm{n}$ & $\%$ \\
\hline 0-30 minutes & 325 & 26 \\
30 min-1 hour & 484 & 38 \\
1-6 hours & 322 & 26 \\
6-24 hours & 91 & 7 \\
$>24$ hours & 43 & 3 \\
\hline
\end{tabular}

Table 8. Distribution of treatments for orofacial trauma patients

\begin{tabular}{lcc}
\hline & $\mathrm{n}$ & $\%$ \\
\hline Symptomatic treatment & 877 & 68 \\
Hospitalization & 148 & 11.6 \\
Department of Plastic Surgery & 101 & 7.8 \\
Denial of treatment & 60 & 4.8 \\
Absence without permission & 46 & 3.5 \\
Department of Orthopedics & 24 & 1.8 \\
Department of Otorhinolaryngology & 23 & 1.7 \\
Department of Pediatrics & 4 & 0.3 \\
Department of Neurology & 4 & 0.3 \\
Department of Ophthalmology & 4 & 0.3 \\
\hline
\end{tabular}


nal studies of patient records..$^{[1-7]}$ In the current study, the assessment of standardized trauma records with information collected at the time of assistance enables the authors to obtain more reliable data relative to previous retrospective studies in which injuries were only registered if signs and/or symptoms were evident at the time of examination.

An obvious difference was observed between genders affected by orofacial trauma. There is a consensus among international studies that boys experience significantly more dental injuries to permanent dentition than girls. ${ }^{[1,13,14]}$ In our study trauma incidence was higher in boys $(65.0 \%)$

Younger children are more susceptible to orodental trauma when they are learning to walk, combined with other behavioral factors, including their curiosity and lack of danger perception; these factors are known to contribute to facial trauma. ${ }^{[1,15-21]}$ In fact, these occurred commonly as children became ambulatory but had not yet developed mature motor skills. ${ }^{[22]}$ The findings of this study show a higher percentage of younger children, especially at the preschool age, with a history of orofacial trauma.

The major etiologic factor of injury was falls (56\%) and primary localization was in the frontal region $(41 \%)$. Wilson et al. described a common scenario of lacerations occuring when a toddler bit the tongue or lip as the mandible struck an object during a fall. ${ }^{[23]}$ This resulted from a younger child's inability to use his or her upper extremities for bracing during a fall. ${ }^{[22,23]}$ In our study, $4 \%$ of the injuries were found in the orodental region, which included lips, teeth, tongue and oral mucosa of the mouth.

The time elapsed between trauma and treatment was divided into five categories in this study: 0-30 $\min (26 \%), 30$ min-1 hour $(38 \%), 1-6$ hours $(26 \%)$, $6-24$ hours $(7 \%)$ and $>24$ hours $(3 \%)$. The percentage of children who came to the ED during the first 24 hours $(97 \%)$ was high compared to other studies. The time delay between injury and treatment fell into the category of "1 day" for most of the cases.

This study underlines the importance of extensive teaching on dental trauma for those who staff the ED. Despite the large number of patients, the hospital had no ED coverage by dentists during the study period. As a result, dental diagnosis and treatment were left to the general and plastic surgeons who staffed the ED. Education and training in the management of dental emergencies by medical practitioners might be inadequate. ${ }^{[2]}$ This means that it is possible that some dental diagnoses were not labeled as such, while some of those labeled as dental were not. The findings of this study revealed that none of the patients who suffered from orodental trauma were sent for dental consultation.
Traumatic injuries in children and adolescents are a common problem and several studies have reported that the prevalence of these injuries has increased during the past few decades. ${ }^{[7]}$ In order to give proper emergency treatment to orofacial trauma cases, it is necessary to set up dental consultation and continuing education for ED physicians on dental emergency procedures.

\section{Acknowledgements}

This study was supported by the Research Found of the University of Istanbul (Project No: UDP-26573)

Conflict-of-interest issues regarding the authorship or article: None declared.

\section{REFERENCES}

1. Assunção LR, Ferelle A, Iwakura ML, Nascimento LS, Cunha RF. Luxation injuries in primary teeth: a retrospective study in children assisted at an emergency service. Braz Oral Res 2011;25:150-6.

2. Skapetis T, Gerzina T, Hu W. Management of dental emergencies by medical practitioners: recommendations for Australian education and training. Emerg Med Australas 2011;23:142-52.

3. Ceallaigh PO, Ekanaykaee K, Beirne CJ, Patton DW. Diagnosis and management of common maxillofacial injuries in the emergency department. Part 5: Dentoalveolar injuries. Emerg Med J 2007;24:429-30.

4. Tham RC, Cassell E, Calache H. Traumatic orodental injuries and the development of an orodental injury surveillance system: a pilot study in Victoria, Australia. Dent Traumatol 2009;25:103-9.

5. Shortridge EF, Moore JR. Use of emergency departments for conditions related to poor oral healthcare: implications for rural and low-resource urban areas for three states. J Public Health Manag Pract 2009;15:238-45.

6. Oliva MG, Kenny DJ, Ratnapalan S. Nontraumatic dental complaints in a pediatric emergency department. Pediatr Emerg Care 2008;24:757-60.

7. Bastone EB, Freer TJ, McNamara JR. Epidemiology of dental trauma: a review of the literature. Aust Dent J 2000;45:29.

8. Stockwell AJ. Incidence of dental trauma in the Western Australian School Dental Service. Community Dent Oral Epidemiol 1988;16:294-8.

9. Perez R, Berkowitz R, McIlveen L, Forrester D. Dental trauma in children: a survey. Endod Dent Traumatol 1991;7:2123.

10. Galea H. An investigation of dental injuries treated in an acute care general hospital. J Am Dent Assoc 1984;109:4348.

11. Oulis CJ, Berdouses ED. Dental injuries of permanent teeth treated in private practice in Athens. Endod Dent Traumatol 1996;12:60-5.

12. Calişkan MK, Türkün M. Clinical investigation of traumatic injuries of permanent incisors in Izmir, Turkey. Endod Dent Traumatol 1995;11:210-3.

13. Altun C, Ozen B, Esenlik E, Guven G, Gürbüz T, Acikel C, Basak F, Akbulut E. Traumatic injuries to permanent teeth in Turkish children, Ankara. Dent Traumatol 2009;25:309-13.

14. Onetto JE, Flores MT, Garbarino ML. Dental trauma in chil- 
dren and adolescents in Valparaiso, Chile. Endod Dent Traumatol 1994;10:223-7.

15. Kramer PF, Zembruski C, Ferreira SH, Feldens CA. Traumatic dental injuries in Brazilian preschool children. Dent Traumatol 2003;19:299-303.

16. Cardoso M, de Carvalho Rocha MJ. Traumatized primary teeth in children assisted at the Federal University of Santa Catarina, Brazil. Dent Traumatol 2002;18:129-33.

17. Fleming P, Gregg TA, Saunders ID. Analysis of an emergency dental service provided at a children's hospital. Int J Paediatr Dent 1991;1:25-30.

18. Galea H. An investigation of dental injuries treated in an acute care general hospital. J Am Dent Assoc 1984;109:4348.
19. Rasmusson CG, Koch G. Assessment of traumatic injuries to primary teeth in general practise and specialized paediatric dentistry. Dent Traumatol 2010;26:129-32.

20. Granville-Garcia AF, de Menezes VA, de Lira PI. Dental trauma and associated factors in Brazilian preschoolers. Dent Traumatol 2006;22:318-22.

21. Skaare AB, Jacobsen I. Primary tooth injuries in Norwegian children (1-8 years). Dent Traumatol 2005;21:315-9.

22. Gordy FM, Eklund NP, DeBall S. Oral trauma in an urban emergency department. J Dent Child (Chic) 2004;71:14-6.

23. Wilson S, Smith GA, Preisch J, Casamassimo PS. Epidemiology of dental trauma treated in an urban pediatric emergency department. Pediatr Emerg Care 1997;13:12-5. 